\title{
Antagonistic Activity, Antimicrobial Susceptibility and Potential Virulence Factors of Enterococcus faecalis
}

\author{
Camila de Souza Carneiro, Norma Suely Evangelista-Barreto, Carla Silva da Silveira-Oliveira, Irana Pain Silva, \\ Thiago Alves Santos de Oliveira and Margarete Alice Fontes Saraiva \\ Center of Agricultural, Environmental and Biological Sciences (CCAAB), Federal University of Recôncavo da Bahia (UFRB), Cruz \\ das Almas, Bahia 44380000, Brazil
}

Received: July 21, 2015 / Accepted: July 28, 2015 / Published: July 30, 2015.

\begin{abstract}
Enterococcus faecalis isolates (87) were phenotypically and genotypically identified and subsequently subjected to the antagonism test and antimicrobial susceptibility. The lipolitic, hemolytic and DNAse activities were identified along with the genes gelE, $c y l L, c y l S, c c f, c p d$ and $c o b$ that, encode virulence determinants. Thirty seven percent of isolates inhibited Listeria monocytogenes (CERELA), Listeria innocuous (CERELA), Staphylococcus aureus (ATCC25932), Lactococcus lactis (IL1403), Micrococcus luteus (ATCC10240) and Enterococcus faecalis (ATCC29212). All strains were sensitive to the ampicillin antibiotic, but 47\% were resistant to at least one antimicrobial agent and $6 \%$ of isolates presented multidrug resistance. Ninety seven percent of isolates contained the gelE gene, but $77 \%$ of these isolates showed gelatinase activity. Presence of $c y l L$ and $c y l S$ genes was observed in $25 \%$ of the isolates, but only 5\% presented hemolytic activity. None isolates showed lipase and DNAse activities. Eight percent of isolates contained the $c c f$ gene and $2 \%$ showed the presence of the $c p d$ and $c o b$ genes. The ability to inhibit pathogenic bacteria, low resistance to antibiotics and absence of virulence factors make some of Enterococcus faecalis strains characterized in the present study promising for exploitation in other applications such as probiotics in aquaculture.
\end{abstract}

Key words: Bivalve mollusks, probiotics, pathogenicity, water.

\section{Introduction}

LABs (lactic acid bacteria) are one of the largest bacteria groups that are industrially important. Enterococcus spp. belongs to this group and has technological characteristics that when used in fermentation processes, contribute to maturation and flavor development in some meat and cheese products $[1,2]$.

The Enterococcus antagonistic capacity allows control of undesirable bacteria in foods [3]. The $E$. faecalis and E. faecium species are the most important within the Enterococcus genus, because they are currently the only species used to produce probiotics intended for human and animal consumption [4]. In foods, their application has been limited because they

Corresponding author: Norma Suely Evangelista-Barreto, D.Sc., professor, research field: food and environmental microbiology. E-mail: nsevangelista@yahoo.com.br. can be used as contamination indicators of fecal origin and some lines are related to nosocomial diseases, diarrhea syndromes in newborns and antimicrobial resistance $[2,5,6]$.

Because they survive in environments with salt concentrations of up to $6.5 \%$, pH between 4.0 and 9.6 and temperatures between $10{ }^{\circ} \mathrm{C}$ and $45{ }^{\circ} \mathrm{C}$, Enterococcus spp. can easily be isolated from soil, water, plants, human, animal, fish and crustacean intestines $[1,7]$ and bivalve mollusks due to their system of feeding by filtration [8].

The inhibitory substances produced by Enterococcus spp. are of interest for bioconservation of fermented seafood or other foods and their use as probiotic cultures in aquaculture [9]. Probiotics are now being successfully developed isolated directly from the digestive tract of organisms and water or from environments impacted by human action because of the 
adaptation and survival capacity these organisms to environments [10]. It is also desirable that the probiotic species have specificity with host species [11].

The incidence of virulence factors as well as resistance to antimicrobials used in human therapy, have contributed for pre selection of microorganisms for use as probiotics, one of the limiting factors vancomycin resistance [12].

Knowledge of antagonistic capacity associated to the antimicrobial resistance profile and virulence mechanisms from E. faecalis can help to understand the complexity of these microorganisms and their potential for application in aquaculture. The authors attempted to generate information on biotechnological potential of these bacteria that are adapted to conditions of the aquatic environment and colonizing mollusk tissues, characterizing the isolates for presence of virulence markers, antimicrobial susceptibility and antagonistic activity.

\section{Materials and Methods}

\subsection{Microorganisms, Growth Conditions and} Phenotypic Identification

The Enterococcus cultures were previously isolated from water and bivalve mollusks (oysters and sururu) in extraction areas in the Recôncavo of Bahia, Brazil. The cultures were kept at $-20{ }^{\circ} \mathrm{C}$ in medium containing glycerol $20 \%(\mathrm{v} / \mathrm{v})$. The cultures were activated in brain and BHI (heart infusion broth). The indicator microorganisms Listeria monocytogenes (CERELA), Listeria inocua (CERELA), Staphylococcus aureus (ATCC25932), Lactococcus lactis (IL1403), Micrococcus luteus (ATCC10240) and Enterococcus faecalis (ATCC29212) were cultured in BHI broth.

The following biochemical tests were carried out to confirm the isolates: Gram coloring, growth at $10^{\circ} \mathrm{C}$ and $45{ }^{\circ} \mathrm{C}$, growth in the presence of $6.5 \% \mathrm{NaCl}$, tellurite reduction and sugar fermentation (arabinose, manitol, sorbitol and glucose with gas production) [13].

\subsection{Antimicrobial Susceptibility}

The antimicrobial susceptibility was performed by disk diffusion method using commercially available antibiotic-containing disks (LABORCLIN, Brazil): ampicillin (AMP, $10 \mu \mathrm{g}$ ), ciprofloxacin (CLO, $5 \mu \mathrm{g}$ ), gentamicin (GEN, $10 \mu \mathrm{g})$, imipenem $(10 \mu \mathrm{g})$, nitrofurantoin (NIT, $300 \mu \mathrm{g}$ ), tetracycline (TET, $30 \mu \mathrm{g}$ ) and vancomycin (VAN, $30 \mu \mathrm{g}$ ) [14]. For control, the following reference strains were used: Escherichia coli ATCC 25922 e Staphylococcus aureus ATCC 25923. The diameters of inhibition zones were recorded to the nearest millimeter and classified as susceptible, intermediate and resistant.

MIC (minimum inhibitory concentration) was determined in strains resistant to antimicrobial test disk diffusion (Kirby-Bauer) according to the broth dilution (macrodilution) technique using Mueller-Hinton broth (Difcoß) [14].

\subsection{Phenotypic Virulence Tests}

The following tests were made: gelatinase, lipase, hemolytic activity and DNAse [15-18]. The formation of a transparent or opalescent halo indicated test positivity.

\subsection{Genotypic Identification}

The isolates were cultured overnight at $37{ }^{\circ} \mathrm{C}$ in BHI broth and centrifuged at $14,000 \mathrm{rpm} / 3 \mathrm{~min}$ [19]. The genomic DNA was extracted using the Wizard $\AA$ Genomic DNA Purification Kit.

To amplify the ribossomal DNA $16 \mathrm{~S}$ by PCR (polymerase chain reaction), the universal primers were used for Enterobactereaceae MD (5'CCCGGGA TCCAAGCTTAAGGAGGTGATCCA) and FD (5'CCGAATTCGTCGACAACAGAGTTTGATCCT) $[19,20]$. The sequencing was carried out by the Macrogen company and the nucleotide sequences compared using sequences deposited in the GenBank.

\subsection{Determining Antagonistic Activity}

The screening was realized by spot-on-the-lawn test 
[21] in BHI agar culture medium at $37^{\circ} \mathrm{C} / 24 \mathrm{~h}$ and an overlay was added using as culture indicators Listeria monocytogenes (CERELA), Listeria inocua (CERELA), Staphylococcus aureus (ATCC25932), Lactococcus lactis (IL1403), Micrococcus luteus (ATCC10240) and Enterococcus faecalis (ATCC29212).

Isolates that presented antagonistic activity were submitted to the well-diffusion-agar test. The supernatant was tested under different treatments: neutralized in $\mathrm{pH} 7.0$ at $100^{\circ} \mathrm{C} / 15 \mathrm{~min}$, in the presence of papain, protease and proteinase $\mathrm{K}$ [22].

\subsection{Determining the Presence of Virulence Genes}

The presence of the virulence genes was verified by PCR (polymerase chain reaction) (Table 1).

\section{Results and Discussion}

\subsection{Identification}

Of the 87 Enterococcus sp. strains used in the biochemical identification and analysis of rDNA $16 \mathrm{~S}$ sequences, 13 strains were identified as Lactococcus sp., 3 as $E$. durans or E. hirae, 11 were unable to identified and 60 strains were identified as E. faecalis, 10 isolates from water, 14 from oysters (Crassostrea rhizophorae) and 36 from sururu (Mytella guyanensis).

Enterococcus faecalis is the dominant species in retail fish and fish-based products ready for consumption in Japan [7]. Even knowing that area suffers with runoff of domestic sewage, due to the lack of sanitation in the region, and E. faecalis is related to the presence of fecal contamination, the strains acquisition directly from the study environment. It has been indicated in the selection of potential probiotic bacteria application, since these have mechanisms which confer better competitive conditions [12].

\subsection{Antagonistic Capacity}

Microorganisms can produce several inhibitory substances, such as metabolism sub products: lactic acid, diacetyl, hydrogen peroxide, lithic agents, exotoxins and bacteriocins [23].

Twenty-two (37\%) of isolates tested presented inhibitory activity. Of these, $82 \%(18 / 22)$ inhibited $L$. lactis (IL1403), 23\% (5/22) presented anti-listerial activity, five isolates inhibited L. inoccua (CERELA) and one isolate inhibited L. monocytogenes (CERELA), $18 \%(4 / 22)$ presented inhibitory activity over $M$. luteus (ATCC10240), 18\% (4/22) inhibited E. faecalis (ATCC29212) and 9\% (2/22) inhibited S. aureus (ATCC25932) (Table 2).

The search Enterococcus bacteriocins producing is gaining interest they can be used to biocontrol pathogenic bacteria such as L. monocytogenes (1). Bacteriocin production in isolates from seafood was reported by Valenzuela et al. [9] and Pinto et al. [24].

The cell-free supernatant was tested in order to obtain more knowledge about the nature of the antagonistic substances produced. Inhibitory activity remained at $76 \%(13 / 22)$ even after passing through treatments with proteolytic enzymes and $\mathrm{pH}$ (7.0) neutralization. Based on the results, the nature of inhibitory compound produced cannot be stated, because the characteristics are atypical when compared with other studies [25], that is, treatment with proteolytic enzymes should promote bacteriocin

Table 1 Primers to amplify the virulence factors in Enterococcus faecalis isolated from water and bivalve mollusk samples.

\begin{tabular}{|c|c|c|}
\hline Target gene & Sequence of primers $\left(5^{\prime}-3^{\prime}\right)$ & Amplicon size \\
\hline gelE & ACCCCGTATCATTGGTTT ACGCATTGCTTTTCCATC & $419 \mathrm{pb}$ \\
\hline$c y l R_{L / S}$ & $\begin{array}{l}\text { CAACAATTTTATGATGGAGGGTAA } \\
\text { TCTTCCATGTAAGCACTCCTTTT }\end{array}$ & $517 \mathrm{pb}$ \\
\hline$c p b$ & $\begin{array}{l}\text { TGGTGGGTTATTTTTCAATTC } \\
\text { TACGGCTCTGGCTTACTA }\end{array}$ & $782 \mathrm{pb}$ \\
\hline$c o b$ & AACATTCAGCAAACAAAGC TTGTCATAAAGAGTGGTCAT & $1,405 \mathrm{pb}$ \\
\hline$c c f$ & GGGAATTGAGTAGTGAAGAAG AGCCGCTAAAATCGGTAAAAT & $543 \mathrm{pb}$ \\
\hline
\end{tabular}


Table 2 Resistance and virulence among Enterococcus faecalis isolates that presented antagonistic potential.

\begin{tabular}{|c|c|c|c|c|c|}
\hline \multicolumn{6}{|l|}{ Profiles } \\
\hline \multirow{2}{*}{ Source } & \multirow{2}{*}{ Strains } & \multirow{2}{*}{ Antagonistic } & \multirow{2}{*}{ Resistence } & \multicolumn{2}{|c|}{ Virulence } \\
\hline & & & & Genotype & Phenotype \\
\hline \multirow{5}{*}{ Water } & EFA14 & $L L, S A, M L$ & TET & gelE, cyl, ccf, cpd & hem \\
\hline & EFA16 & $L I, E F$ & & gelE, cob & \\
\hline & EFA18 & $L I, E F$ & & gelE, ccf & \\
\hline & EFA20 & $L L, M L$ & IMP*, TET & gelE, cyl, cpd & hem \\
\hline & EFA21 & $L I, L L$ & & gelE, cyl, ccf, cpd & \\
\hline \multirow{8}{*}{ Oysters } & EFOS26 & $L L$ & IMP & gelE, cyl, cpd & gel \\
\hline & EFOS27 & $L L$ & VAN* & gelE, cyl, ccf & gel \\
\hline & EFOS28 & $L L$ & GEN*, TET & gelE, cyl & gel \\
\hline & EFOS29 & $L L$ & GEN* & gele, cyl & gel \\
\hline & EFOS30 & $L L$ & GEN*, VAN & gelE, cyl & gel \\
\hline & EFOS31 & $L L$ & GEN* & gelE, cyl & gel \\
\hline & EFOS33 & $L L$ & & gelE & gel \\
\hline & EFOS34 & $L I$ & GEN, IMP & gelE & gel \\
\hline \multirow{9}{*}{$\begin{array}{l}\text { Mytella } \\
\text { guyanensis }\end{array}$} & EFSU40 & $L L$ & CIP, GEN* & gelE, cyl & gel \\
\hline & EFSU41 & $L L$ & GEN* & gelE, $c y l$ & gel \\
\hline & EFSU42 & $M L, E F$ & GEN & gelE & gel \\
\hline & EFSU50 & $L L$ & CIP*, GEN & gelE & gel, hem \\
\hline & EFSU57 & $L L$ & GEN, VAN* & gelE, cyl & gel \\
\hline & EFSUP64 & $L M, L I, L L, S A, M L, E F$ & GEN & gelE, cyl & gel \\
\hline & EFSUP65 & $L L$ & GEN* & gelE & gel \\
\hline & EFSUP84 & $L L$ & GEN* & gelE & gel \\
\hline & EFSUP87 & $L L$ & GEN & gelE & gel \\
\hline
\end{tabular}

LM-Listeria monocytogenes (CERELA), LI-Listeria inocua (CERELA), LL-Lactococcus lactis (IL1403), SA-Staphylococcus aureus (ATCC25932), ML-Micrococcus luteus (ATCC10240), EF-Enterococcus faecalis (ATCC29212), CIP-ciprofloxacin, GEN—gentamicin, TET — tetracycline, IMP—imipemem, VAN—vancomycin, *—intermediate resistance, gel—perfil gelatinolytic, hemolytic profile.

inactivation because they are composed of peptides [24].

All the inhibitory substances were considered heat sensitive because they lost their activity after treatment at $100{ }^{\circ} \mathrm{C} / 15 \mathrm{~min}$. Enterococcus bacteriocins are usually characterized as heat resistant, and activity loss in the substrate studied was attributed to the presence of a peptide compound from thermolabile fraction [26].

Bacteriacin ST15, produced by Enterococcus mundtii, has also been reported because it loses all its activity after treatment at $90-121^{\circ} \mathrm{C} / 10 \mathrm{~min}$ [27]. The bacteriocin described in the study by Pinto et al. [24] partially lost activity after treatment at different temperatures $\left(90-120^{\circ} \mathrm{C}\right)$.

Recently, the use of bacteria from the sea and producers of inhibitory substances against pathogenic bacteria in aqua systems [3] has become more common as an efficacious alternative to ensure the organisms health, minimizing the use of antimicrobials [12].

Table 2 shows that isolates from water and $M$. guyanensis presented similar results to the antagonistic potential, so that they were capable of inhibiting practically the same culture indicators, except for $L$. monocytogenes (CERELA) that was inhibited only by one $M$. guyanensist isolate. It is also possible to see that the isolates that presented hemolytic activity came from these two origins. This similarity was because the aquatic environment is considered highly competitive and adverse, and the sediment where $M$. guyanensis is found buried contains a high concentration of microbial cells. 


\subsection{Antimicrobial Susceptibility Profile}

All the isolates were sensitive only to ampicillin $(100 \%)$ and nitrofurantoin (98\%). Resistance to at least one antimicrobial agent was observed in $47 \%$, although strains with high intermediate resistance were observed in $70 \%$ of the isolates (Table 3 ).

Enterococcus resistance to antimicrobials results from their need for survival and persistence in highly competitive environments [28]. Resistance to antimicrobial agents in aquatic microorganisms indicates ecosystem change by human action, especially when antibiotics are released into sewers through the urine, feces and eventually animal carcasses [29].

Presence of antimicrobial compounds in aquatic environments is a cause for concern, because even when they are present at low concentrations they are considered a risk to the ecosystems due to their interference in biological processes [30]. The aquatic environment is considered the most efficient niche in genetic material exchange between microorganisms due to the presence of mobile elements such as plasmids and transposons. This exchange favors the development of pathogenic and multiresistant bacteria to antimicrobials [31].

High resistance was observed to gentamicin and tetracycline. Multi-resistance was observed in $6 \%$ $(3 / 60)$ of the isolates, $2 \%(1 / 60)$ were resistant to imipenem and tetracycline, $2 \%(1 / 60)$ to gentamicin and tetracycline, $2 \%(1 / 60)$ to gentamicin and imipenem. Incidence of multiple resistance to antimicrobials in bacteria allows a better understanding of the strains, antimicrobial consumption and their effects on cultured organisms and human diseases [32].

According to the literature, the most important resistance phenotypes are those related to the aminoglycosides, beta lactams and glycopeptides because they are used in the treatment of Enterococcus infections. Although the genus has been described as resistant to low levels of aminoglycosides and tetracycline in clinical isolates, the high frequency of resistance to gentamicin has been reported in several strains isolated from food and water worldwide [7, 33].

Vancomycin-resistant strains are emerging as the global menace to public health. In the present study, only one isolate presented resistance profile and $7 \%$ $(4 / 60)$ were classified with intermediate resistance and are not indicated for biotechnological application (Table 3). Using antimicrobials with intermediate sensitivity selects resistant strains [34].

Intrinsic resistance of Enterococcus to vancomycin is due to alterations in the cell wall synthesis.

Table 3 Microbial susceptibility and MIC (minimum inhibitory concentration) of Enterococcus faecalis isolates in water and bivalve mollusk samples.

\begin{tabular}{|c|c|c|c|c|}
\hline \multirow[b]{2}{*}{ Antimicrobials } & \multicolumn{3}{|c|}{$\%$ susceptibility/number of isolates } & \multirow[b]{2}{*}{$\mathrm{MIC}(\mu \mathrm{g})$} \\
\hline & Sensitive & Intermediate & Resistant & \\
\hline \multicolumn{5}{|l|}{ Aminoglycosides } \\
\hline Gentamicin $(10 \mu \mathrm{g})$ & $35_{(21 / 60)}$ & $40_{(24 / 60)}$ & $25_{(15 / 60)}$ & $60 \mu \mathrm{g}$ \\
\hline \multicolumn{5}{|l|}{ Betalactamics } \\
\hline Ampicillin $(30 \mu \mathrm{g})$ & $100_{(60 / 60)}$ & 0 & 0 & 0 \\
\hline Imipenem $(10 \mu \mathrm{g})$ & $82_{(49 / 50)}$ & $10_{(6 / 60)}$ & $8_{(5 / 60)}$ & $50 \mu \mathrm{g}$ \\
\hline \multicolumn{5}{|l|}{ Glycopeptides } \\
\hline Vancomycin $(30 \mu \mathrm{g})$ & $90_{(54 / 60)}$ & $7_{(4 / 60)}$ & $2_{(1 / 60)}$ & $70 \mu \mathrm{g}$ \\
\hline \multicolumn{5}{|l|}{ Nitrofuran } \\
\hline Nitrofurantoin $(300 \mu \mathrm{g})$ & $98_{(59 / 60)}$ & $2_{(1 / 60)}$ & 0 & 0 \\
\hline \multicolumn{5}{|l|}{ Quinolone } \\
\hline Ciprofloxacin $(5 \mu \mathrm{g})$ & $92_{(55 / 60)}$ & $6_{(4 / 60)}$ & $2_{(1 / 60)}$ & $20 \mu \mathrm{g}$ \\
\hline \multicolumn{5}{|l|}{ Tetraciclina } \\
\hline Tetracycline $(30 \mu \mathrm{g})$ & $85_{(51 / 60)}$ & $5_{(3 / 60)}$ & $10_{(6 / 50)}$ & $80 \mu \mathrm{g}$ \\
\hline
\end{tabular}


Vancomycin resistance is a limit for their use as probiotics $[1,13]$.

The minimum inhibitory concentration of resistant isolates was considered low compared to the limits established by the CLSI [14], that is, the largest MIC (over five times the limit) was observed for ciprofloxacin, tetracycline, and smallest CIM (over twice the limit) was obtained for vancomycin (Table $3)$.

Enterococcus spp. has several intrinsic or acquired resistance mechanisms. Acquired resistance occurs by the transfer of genes present in plasmids through the conjugation of intra and interspecific bacteria [3]. The antimicrobial agents for animal and human use when discharged in the water environment alter the ecological balance [36] and increase the incidence of resistant bacteria in water environments and seafood. Although the resistance transference indices in foodstuffs and aquatic environments are lower than in clinical indices [12], microorganism accumulation in bivalve mollusks tissues may facilitate this transference.

Culture-resistant Enterococcus can be introduced into the food chain and the human intestine, promoting transference of resistance factors between bacteria from intestinal microflora [13]. The safe use of $E$. faecalis resistant as probiotic cultures is important to ensure that these resistant factors will not be transferred [12].

\subsection{Virulence Factors}

Genetic analysis showed that $97 \%$ of isolates had the structural gene gelE responsible for producing the gelatinase enzyme in E. faecalis, however gelatinolytic activity was observed in only $77 \%$. None isolates were positive for the lipase and Dnase tests (Fig. 1).

Enterococcus spp. can produce some proteases that help them to survive in the medium where they live and are produced only when necessary [37]. Gelatinase is a metalloprotease that hydrolyses gelatin, collagen, hemoglobin and other bioactive peptides. Although this enzyme is related to the induction of inflammatory processes and biofilm production [38-40], its proteolytic action is considered advantageous for industry [9].

Birri et al. [28] who studied the gelatinolytic profile in bacteria of the Enterococcus genus and reported greatest prevalence in the E. faecalis species.

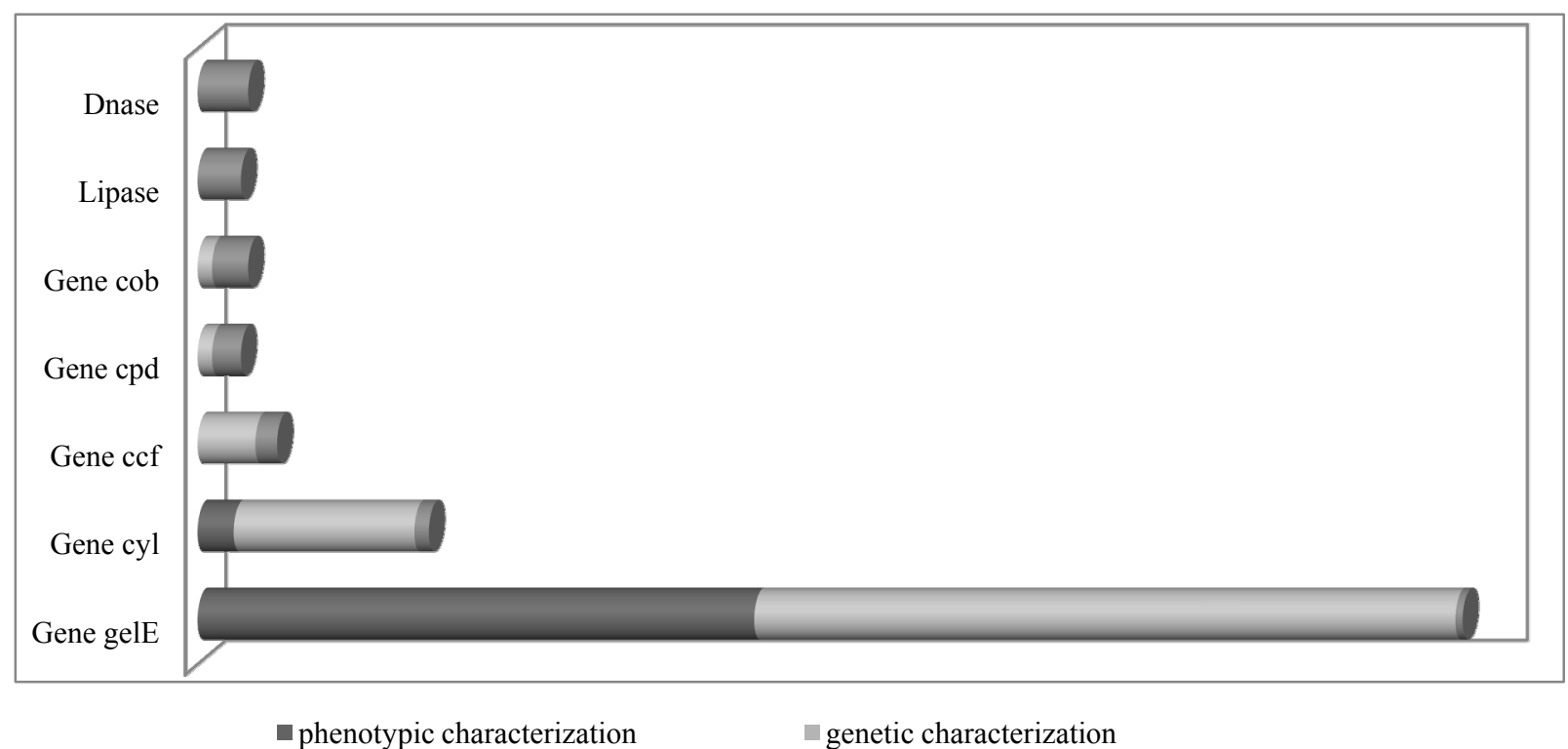

Fig. 1 Profile of the presence of pathogenicity-related genes in cultures of Enterococcus faecalis isolated from water and bivalve mollusk samples. 
Cormelato et al. [40] compared gelatinase activity in $E$. faecium and E. faecalis isolates and also observed a greater presence of the gelE gene in E. faecalis. According to these authors isolates that presented the gelE gene were not capable of degrading gelatin that implies lack of gene expression.

Although $25 \%$ of isolates contained the $c y l L_{L / S}$ gene that encodes cytolysin, only 5\% presented hemolytic activity (Fig. 1). Cytolysin production is due to an operon consisting of $\mathrm{H}$ genes, principally the cylA gene, because without it the expression of $c y l L_{L / S}$ structural gene does not occur [28]. The $C y l L_{L / S}$ structural gene does not appear to be an exclusive characteristic in isolates from clinical samples because it can be detected in the most diverse samples studied, including soil, water and foodstuffs [6].

Cytolysin is a peptide exclusive to the Enterococcus genus that has inhibitory activity against gram positive bacteria, encoded by the $C y l L_{L / S} \mathrm{~g}$ structural gene usually located in the plasmodium. This gene is also responsible for causing hemolysis in humans [2]. Lines that express protein present tenfold pathogenicity, which contributes to their proliferation in the bloodstream because their activity takes place on the lysis of red blood cells, macrophages and neutrophils [38].

Hemolytic activity is not only related to the presence of cylA gene and other factors should be taken into consideration, such as the environment and the presence of other genes in the operon [28]. Hemolytic activity and the $c y l$ A gene were not observed in a study on E. faecium strains isolated from seafood [9], although Valenzuela et al. [5] reported that in $17 \%$ of $E$. faecalis isolates from plants and animals that contained the $c y l A$ gene, there was no hemolytic activity.

Genes responsible for encoding the chemoreceptors were present in $8 \%(4 / 60), 2 \%(1 / 60)$ and $2 \%(1 / 60)$ of isolates for the genes $c c f, c p d$ and $c o b$, respectively (Fig. 1). These genes can promote the resistance acquisition to antimicrobials, virulence factors and other characteristics from Enterococcus spp. strains by forming cellular aggregates. Phermones mediate the conjugation facilitating the exchange of genetic information [15].

The low incidence of the $c c f$, $c p d$ and $c o b$ genes means that they are not a concern for the safe use of $E$. faecalis strains [9].

Environmental factors can influence the genetic expression of microorganisms, so that some silent genes become active because of changes in the environment and the conditions found in the gastrointestinal tract of the host $[15,39]$.

The presence of a specific gene does not mean its phenotypic expression, as reported for E. faecalis isolates from several sources including water and foods $[2,15,28,35,39]$. Hemolytic activity serves as an indicator of pathogenicity potential in Enterococcus spp. and this is a limiting factor for its use as probiotic and/or as starter culture in foods. The probiotic potential of E. faecalis could be safely exploited in $30 \%$ of isolates studied, because they did not present resistance to vancomycin and hemolytic profile.

\section{Conclusions}

The inhibitory activity presented by the E. faecalis isolates is promising regarding exploitation of its biotechnological potential, especially when considering microorganisms with probiotic potential for aquaculture.

\section{Acknowledgments}

The authors thank CAPES/PNPD and the collaboration of Prof. Dr. Jorge Teodoro de Souza (Microorganisms Genetics Laboratory), Profa. Dra. Soraia Fonteles (Ichthyogenetics Laboratory), the researcher Dr. Emanuel Felipe Medeiros Abreu (Brazilian Enterprise for Agricultural Research-EMBRAPA) and all the staff of the Food and Environment Microbiology Laboratory.

\section{References}

[1] Ogier, J. C., and Serror, P. 2008. "Safety Assessment of 
Dairy Microorganisms: The Enterococcus Genus." International Journal Food Microbiology 126: 291-301.

[2] Barbosa, J., Gibbs, P. A., and Teixeira, P. 2010. "Virulence Factors among Enterococci Isolated from Traditional Fermented Meat Products Produced in the North of Portugal." Food Control 21 (5): 651-6. doi:10.1016/j.foodcont.2009.10.002.

[3] Valenzuela, A. S., Omar, N. B., Abriouel, H., López, R. L., Veljovic, K., Cañamero, M. M., Topisirovic, M. K. L., and Gálvez, A. 2009. "Virulence Factors, Antibiotic Resistance, and Bacteriocins em Enterococci from Artisan Foods of Animal Orgin." Food Control 20: 381-5.

[4] Franz, C. M. A. P., Huch, M., Abriouel, H., Holzapfel, W., and Gálvez, A. 2011. "Enterococci as Probiotics and Thier Implications in Food Safety." International Journal of Food Microbiolog 151: 125-40.

[5] Valenzuela, A. S., Omar, N. B., Abriouel, H., López, R. L., Ortega, E., Cañamero, M. M., and Gálvez, A. 2008. "Risk Factors in Enterococci Isolated from Foods in Marocco: Determination of Antimicrobial Resistance and Incidence of Virulencia Trans." Food and Chemical Toxicology 46: 2648-52.

[6] Billstrom, H., Lund, B., Sullivan, A., and Nord, C. E. 2008. "Virulence and Antimicrobial Resistence in Clinical Enterococus faecium." International Journal of Antimicrobial Agents 32 (11): 374-7. doi: 10.1016/j.ijantimicag.2008.04.026.

[7] Hammad, A. M., Shimamoto, T., and Shimamoto, T. 2014. "Genetic Characterization of Antibiotic Resistance and Virulence Factors in Enterococcus spp. from Japanese Retail Ready-to-Eat Raw Fish.” Food Microbiology 38: 62-6.

[8] Martines, D. I., and Oliveira, A. J. F. C. 2010. "Faecal Bacteria in Perna perna (Linnaeus, 1758) (Mollusca: bivalvia) for Biomonitoring Coastal Waters and Seafood Quality.” Brazilian Journal of Oceanography 58: 29-35.

[9] Valenzuela, A. S., Benomar, N., Abriouel, H., Cañamero, M. M., and Gálvez, A. 2010. "Isolation and Indentification of Enterococcus faecium from Seafoods: Antimicrobial Resistance and Production of Bacteriocin-Like Substances." Food Microbiology 27: 955-61.

[10] Resende, E. K. 2009. "Pesquisa em Rede em Aquicultura: Bases Tecnológicas para o Desenvolvimento Sustentável da Aquicultura no Brasil." Revista Brasileira de Zootecnia 38: 52-57.

[11] Ferreira, A. H. C., Araripe, M. N. B. A., Monteiro, C. A. B., Lopes, J. B., and Araripe, H. G. A. A. 2012. "Uso de probióticos na aquicultura-Revisão.” Revista Eletrônica Nutritime. 9 (5): 1965-80.

[12] Concha-Meyer, A., Schôbitz, R., Brito, C., and Fuentes, R. 2011. "Lactic Acid Bacteria in an Alginate Film Inhibit Listeria monocytogenes Growth on Smoked Salmon."
Food

Control

22:

485-9.

doi:10.1016/j.foodcont.2010.09.032.

[13] Klein, G. 2003. "Taxonomy, Ecology and Antibiotic Resistance of Enterococci from Food and the Gastro-Intestinal Tract." International Journal of Food Microbiology 88: 123-31.

[14] Clinical Laboratory Standards Institute (CLSI). 2010. Performance Standards for antimicrobial testing. Twentieth Informational Supplement, M100-S20. Wayne, PA: CLSI.

[15] Eaton, T. J., and Gasson, M. J. 2001. "Molecular Screening of Enterococcus Virulence Determinants and Potential for Genetic Exchange between Food and Medical Isolates." Applied and Environmental Microbiology 67 (4): 1628-35.

[16] Tiago, I., Teixeira, I., Silva, S., Chung, P., Veríssimo, A., and Manaia, C. M. 2004. "Metabolic and Genetic Diversity of Mesophilic and Thermophilic Bacteria Isolated from Composted Municipal Sludge on Poly-E-Caprolactones." Current Microbiology 49: 407-14.

[17] Omar, N. B., Castro, A., Lucas, R., Abriouel, H., Yousif, N. M. K., Franz, C. M. A. P. et al. 2004. "Functional and Safety Aspects of Enterococci Isolated from Different Spanish Foods." Systematic Applied Microbiology 27: 118-30.

[18] Austin, A., Austin, D., Sutherland, R., Thompson, F., and Swings, J. 2005. "Pathogenicity of Vibrios to Rainbow Trout (Oncorhynchus mykiss, Walbaum) and Artemia nauplii." Environmental Microbiology 7 (9): 1488-95. doi:10.1111/j.1462-2920.2005.00847.x.

[19] Manero, A., and Blanch, A. R. 2002. "Identification of Enterococcus spp. Based on Specific Hybridisation with 16S rDNA Probes." Journal of Microbiological Methods 50: $115-21$.

[20] Weisburg, W. G., Barns, S. M., Pelletier, D. A., and Lane, D. J. 1991. "16S Ribosomal DNA Amplification for Phylogenetic Study." Journal of Bacteriology 173: 697-703.

[21] Harris, L. J., Daeschel, M. A., Stiles, M. E., and Klaenhammer, T. R. 1989. "Antimicrobial Activity of Lactic Acid Bacteria against Listeria monocytogenes." Journal of Food Protection 52 (6): 384-7.

[22] Schillinger, U., and Lucke, F. K. 1989. "Antibacterial Activity of Lactobacillus Sake Isolated from Meat." Applied Environment Microbiology 55 (8): 1901-6.

[23] Tagg, J. R., Dajani, A. S., and Wannamaker, L. W. 1976. "Bacteriocins of Gram-Positive Bacteria." Bacteriology Reviews 40 (3): 722-56.

[24] Pinto, A. L., Fernandes, M., Pinto, C., Albano, H., Castilho, F., Teixeira, P., and Gibbs, P. A. 2009. "Characterization of Anti-listeria Bacteriocins Isolated from Shellfish: Potential Antimicrobials to Control 
Non-fermented Seafood." International Journal of Food Microbiology 129: 50-8.

[25] Abriouel, H., Omar, N. B., Molinos, A. C., López, R. L., Grande, M. J., Martínez-Viedma, P., Ortega, E., Cañamero, M. M., and Galvez, A. 2008. "Comparative Analysis of Genestic Diversity and Incidence of Virulence Factors and Antibiotic Resistance among Enterococcal Populations from Raw Fruit and Vegetable Food, Water and Soil, and Clinical Samples." International Journal of Food $\begin{array}{llll}\text { Microbiology } & 123 & \text { (3): } & 38-49 .\end{array}$ doi:10.1016/j.ijfoodmicro.2007.11.067.

[26] Schôbitz, R., González, C., Villarreal, K., Horzella, M., Nahuelquín, Y., and Fuentes, R. A. 2014. "Biocontroller to Eliminate Listeria momocytogenes from the Food Processing Environment." Food Control 36: 217-23.

[27] De Kwaadsteniet, M., Todorov, S. D., Knoetze, H., and Dicks, L. M. T. 2005. "Characterization of a 3944 Da Bacteriocin, Produced by Enterococcus mundtii ST15, with Activity against Gram-Positive and Gram-Negative Bacteria." International Journal of Food Microbiology 105: 433-44.

[28] Birri, D. J., Brede, D. A., Tessema, G. T., and Nes, I. F. 2013. "Bacteriocin Production, Antibiotic Susceptibility and Prevalence of Haemolytic and Gelatinase Activity in Faecal Lactic Acid Bacteria Isolated from Healthy Ethiopian Infants." Microbial Ecology 65 (2): 504-16. doi:10.1007/s00248-012-0134-7.

[29] Baquero, F., Martínez, J. L., and Cantón, R. 2008. "Antibiotics and Antibiotic Resistance in Water Environments." Current Opinion in Biotechnology 19 (3): 260-5. doi:10.1016/j.copbio.2008.05.006.

[30] Huerta, B., Marti, E., Gros, M., López, P., Pompêo, M., Armengol, J., Barceló, D., Balcázar, J. L., Rodríguez-Mozaz, S., and Marcé, R. 2013. "Exploring the Links between Antibiotic Occurrence, Antibiotic Resistance, and Bacterial Communities in Water Supply Reservoirs." Science of the Total Environmental 456-457: 161-70.

[31] Evangelista-Barreto, N. S., Carvalho, F. C. T., Menezes, F. G. R., Silva, C. M., Rocha, R. S, Sousa, O. V., and Fermandes-Vieria, R. H. S. 2012. "Bathing Suitability and Antimicrobial Susceptibility of Enterococcos in Tropical Coastal Waters." Arquivos de Ciências do Mar 45 (1): 62-8.

[32] Zheng, S., Qiu, X., Chen, B., Yu, X., Liu, Z., Zhong, G., Li, H., Chen, M., Sun, G., Huang, H., and Yu, W. 2011.
"Antibiotics Pollution in Jiulong River Estuary: Source, Distribution and Bacterial Resistance." Chemosphere 84: 1677-85.

[33] Macedo, A. S., Freitas, A. R., Abreu, C., Machado, E., Peixe, L., Sousa, J. C., and Novais, C. 2011. "Characterization of Antibiotic Resistant Enterococci Isolated from Untreated Waters for Human Consumption in Portugal." International Journal of Food Microbiology 145: 315-9.

[34] Carvalho, F. C. T., Evangelista-Barreto, N. S., Reis, C. M. F., Hofer, E., and Vieira, R. H. S. F. 2009. "Susceptibilidade Antimicrobiana de Salmonella spp. Isolade de Fazendas de Carcinicultura do Estado do Ceará." Revista Ciência Agronômica 40 (2): 549-56.

[35] Arciola, C. R., Baldassarri, L., Campoccia, D., Creti, R., Pirini, V., Huebner, J., and Montanaro, L. 2008. "Strong Biofilm Production, Antibiotic Multi-Resistance and High Gele Expresssion in Epidemic Clones of Enterococcus faecalis from Orthopaedic Implant Infections." $\begin{array}{lll}\text { Biomaterials } & 20 & \text { (2): } \quad 580-6 .\end{array}$ doi:10.1016/j.biomaterials.2007.10.008.

[36] Regitano, J. B., and Leal, R. M. P. 2010. "Comportamento e Impacto Ambiental de Antibióticos Usados na Produção Animal Brasileira." Revista Brasileira de Ciência do Solo 34: 601-16.

[37] Park, S. Y., Kim, K. M., Lee, J. H., Seo, S. J., and Lee, I. H. 2007. "Extracellular Gelatinase of Enterococcus faecalis Destroys a Defense System in Insect Hemolymph and Human Serum." Infection and Immunity 74 (4): 1861-9.

[38] Gomes, B. C., Esteves, C. T., Palazzo, I. C. V., Darini, A. L. C., Felis, G. E., Sechi, L. A., Franco, B. D. G. M., and DE Martinis, E. C. P. 2008. "Prevalence and Characterization of Enterococcus spp. Isolated from Brazilian Foods." Food Microbiology 25: 666-75.

[39] Wang, L., Dong, M., Zheng, J., Song, Q., Yin, W., Li, J., and Niu, W. 2011. "Relationship of Biofilm Formation and Gele Gene Expression in Enterococcus faecalis Recovered from Root Canals in Patients Requiring Endodontic Retreatment." Clinical Research 37 (5): 631-6.

[40] Comerlato, C. B., De Resende, M. C. C., Caierão, J., and D'Azevedo, P. A. 2013. "Presence of Virulence Factors in Enterococcus faecalis and Enterococcus faecium Susceptible and Resistant to Vancomycin." Memórias do Instituto Oswaldo Cruz 108 (5): 590-5. 